\title{
SOSIALISASI PERMAINAN ULAR TANGGA UNTUK MENINGKATKAN PERILAKU HIDUP BERSIH DAN SEHAT DI SDN MARGAMULYA KECAMATAN SINGAPARNA KABUPATEN TASIKMALAYA TAHUN 2018
}

\author{
OLEH :
}

\author{
Sinta Fitriani, S.KM, M.KM \\ Fenty Agustini, SST,Mkes \\ (email : taniesa1571@gmail.com)
}

\section{A. DASAR PEMIKIRAN}

Anak usia sekolah merupakan kelompok usia yang kritis karena pada usia tersebut seorang anak rentan terhadap masalah kesehatan. Masalah kesehatan yang dihadapi oleh anak usia sekolah pada dasarnya cukup kompleks dan bervariasi. Peserta didik pada tingkat Sekolah Dasar (SD) misalnya, masalah kesehatan yang muncul biasanya berkaitan dengan kebersihan perorangan dan lingkungan, sehingga isu yang lebih menonjol adalah perilaku hidup bersih dan sehat, seperti cara menggosok gigi yang benar, mencuci tangan pakai sabun, dan kebersihan diri lainnya (Depkes RI : 2004)

Perilaku hidup bersih dan sehat adalah perilaku kesehatan yang dilakukan atas kesadaran sehingga setiap orang dapat menolong dirinya sendiri di bidang kesehatan dan berperan aktif dalam kegiatan - kegiatan kesehatan di masyarakat. Pada tatanan sekolah terdapat 8 indikator untuk perilaku hidup bersih dan sehat yaitu : jajan di kantin sekolah, mencuci tangan dengan air bersih yang mengalir dan sabun, menggunakan jamban sehat, mengikuti kegiatan olahraga dan aktivitas fisik di sekolah, memberantas jentik nyamuk, tidak merokok di sekolah, menimbang berat badan dan mengukur tinggi badan setiap bulan, serta membuang sampah pada tempatnya (Depkes RI, 04.

Pada era globalisasi ini banyak tantangan bagi peserta didik yang dapat mengancam kesehatan fisik dan jiwanya. Tidak sedikit anak yang menunjukkan perilaku tidak sehat, seperti lebih suka mengkonsumsi makanan tidak sehat yang tinggi lemak, gula, garam, rendah serat, meningkatkan resiko hipertensi, diabetes, obesitas dan sebagainya. Siswa sebelum makan tidak mencuci tangan terlebih dahulu, sehingga memungkinkan masuknya bibit penyakit kedalam tubuh. Hal ini mengacu pada pemikiran Hamiyah dan Jauhar (2015) bahwa perilaku tidak sehat ini juga disebabkan oleh lingkungan yang tidak sehat, seperti kurang bersihnya rumah, sekolah, atau lingkungan masyarakatnya.

Hasil penelitian yang dilakukan oleh Hermiyanti (2016:14) bahwa Sekolah Dasar Bersih Sehat (SDBS) adalah Sekolah Dasar yang warganya secara terus-menerus membudayakan PHBS, dan memiliki lingkungan sekolah yang bersih, indah, sejuk, segar, rapih, tertib, dan aman. Menurut Panduan Pengembangan Model Sekolah Sehat di Indonesia (2009: 4), manfaat yang didapat dari program Sekolah Sehat antara lain: 1) bagi masyarakat yaitu sebagai tempat menghasilkan siswa yang mempunyai budaya hidup sehat dan aktif, 
2) bagi pemerintah yaitu sebagai tempat pembelajaran yang dapat dijadikan percontohan bagi sekolah-sekolah lain karena diharapkan sekolah tersebut dapat menghasilkan sumber daya yang berkualitas, dan 3) bagi swasta atau dunia kerja yaitu dapat memberi peluang pada swasta untuk berperan dalam pengembangan Sekolah Sehat.( Proverawati dan E. Rahmawati : 2011)

Kemendiknas Direktorat Jenderal Pendidikan Dasar (2009: 9) menjelaskan bahwa standar Sekolah Sehat meliputi: 1) Standar fisik sekolah yang meliputi: Bangunan sekolah yang memenuhi pembakuan standar minimal Depdiknas, sekolah memiliki akreditasi dari pemerintah, minimal B, sekolah yang memenuhi persyaratan kesehatan (fisik, mental, lingkungan), sekolah yang memiliki pagar, sekolah yang memiliki ruang terbuka yang memadai untuk pembelajaran pedidikan jasmani, dan sekolah memiliki sertifikat hak milik (SHM). 2) Standar sarana prasarana meliputi: memiliki sarana prasarana untuk pendidikan kesehatan yang memadai, memiliki sarana prasarana untuk pendidikan jasmani, memiliki sarana prasarana penunjang kegiatan UKS, 3) Standar ketenagaan yang meliputi: memiliki guru pendidikan jasmani, olahraga dan kesehatan, memiliki guru pembina UKS, memiliki kader kesehatan sekolah (dokterkecil, kader kesehatan remaja), 4) Standar peserta didik yang meliputi: memiliki derajat kesehatan yang optimal, tumbuh kembang secara optimal, dan memiliki tingkat kebugaran jasmani yang optimal.

Program Sekolah Sehat perlu disosialisasikan dan dilakukan dengan baik melalui pelayanan kesehatan yang didukung secara mantap dan memadai oleh sektor terkait lainnya, seperti partisipasi masyarakat, dunia usaha, dan media massa. Hal tersebut sesuai dengan pemikiran Hamiyah dan Jauhar (2015:267) yang menyatakan bahwa sekolah sebagai tempat berlangsungnya proses pembelajaran harus menjadi "Sekolah Sehat", yaitu sekolah yang dapat meningkatkan derajat kesehatan warga sekolahnya. Upaya ini dilakukan karena sekolah memiliki lingkungan kehidupan yang mencerminkan hidup sehat. Mengupayakan pelayanan kesehatan yang optimal, sehingga terjamin berlangsungnya proses pembelajaran dengan baik dan terciptanya kondisi yang mendukung tercapainya kemampuan peserta didik untuk berperilaku hidup sehat. Pendapat diatas sejalan dengan penelitian Irwandi (2016:492- 495) bahwa program sekolah berupa operasi semut, Sabtu bersih, upacara bendera, senam pagi, doa bersama, aubade dan UKS, merupakan kegiatan yang efektif untuk menumbuhkembangkan perilaku hidup sehat, yang melibatkan peran kepala sekolah, guru dan personil sekolah. (Hijjang, P : 2009)

SD Negeri Margamulya merupakan salah satu sekolah dasar yang berada di wilayah Kecamatan Singaparna. Sekolah dengan jumlah siswa 225 orang. Kondisi lingkungan di sekolah tersebut adalah sebagai berikut : Sumber air bersih yang digunakan bersumber dari PDAM, akan tetapi kecukupan jumlah air tidak mencukupi kebutuhan pengguna. Jamban yang dimiliki di SDN Margamulya adalah 6 buah jamban untuk siswa tidak sesuai rasio dan tidak ada pemisahan antara jamban siswa laki laki dan perempuan. Selain itu terdapat 2 jamban untuk guru. Saluran pembuangan air limbah di sekolah tersebut langsung ke selokan 
belakang sekolah. Berdasarkan wawancara dengan salah satu guru sekolah menyatakan bahwa di SDN Margamulya terdapat 1 buah ruang UKS akan tetapi program UKS tidak berjalan maksimal. Sekolah ini tidak memiliki kantin. Anak anak jajan diluar sekolah pada PJAS. Menurut guru belum ada aturan terkait jajan di sekolah tersebut. (Supriyani : 2017)

\section{B. TUJUAN KEGIATAN}

Tujuan dari kegiatan ini adalah : Meningkatkan perilaku hidup bersih dan sehat di sekolah SDN Margamulya.

\section{BENTUK KEGIATAN}

1. Melakukan identifikasi permasalahan perilaku hidup sehat di sekolah

2. Melakukan penyuluhan tentang PHBS Sekolah

3. Sosialisasi permainan ular tangga PHBS sekolah untuk meningkatkan PHBS disekolah

\section{SASARAN}

Seluruh warga sekolah SDN Margamulya terdiri dari 11 guru, 234 siswa dan 2 penjaga sekolah

\section{E. WAKTU DAN TEMPAT PELAKSANAAN}

Kegiatan ini dilaksanakan :

\begin{tabular}{|l|l|l|l|}
\hline No & \multicolumn{1}{|c|}{ Kegiatan } & \multicolumn{1}{|c|}{ Waktu pelaksanaan } & \multicolumn{1}{|c|}{ Penanggung jawab } \\
\hline 1 & Perijinan kegiatan & 08 Oktober2018 & Waranda dan Rengga \\
\hline 2 & Survey mawas diri & 12 Oktober 2018 & Mira dan Dinda \\
\hline 3 & $\begin{array}{l}\text { Musyawarah Masyarakat } \\
\text { sekolah }\end{array}$ & 13 Oktber 2018 & \\
\hline 4 & Penyuluhan & $\begin{array}{l}9-23 \text { November } \\
2018\end{array}$ & $\begin{array}{l}\text { Sinta Fitriani } \\
\text { Rengga } \\
\text { Waranda }\end{array}$ \\
& & & Mira \\
& & & Dinda \\
& & Ai Ulfah \\
Widi \\
\end{tabular}

\section{F. HASIL KEGIATAN}

Kegiatan yang dilaksanakan mencakup :

1. Survey mawas diri

Hasil survey mawas diri ditemukan beberaa permasalahan PHBS sekolah sebagai berikut:

a. Ketersediaan jamban tidak memenuhi standar 
b. Tidak ada kantin sehat

c. Kebersihan diri siswa masih kurang

d. Tidak ada sarana tempat cuci tangan

e. Masih ada guru yang merokok disekolah

2. Musyawarah masyarakat sekolah

Musyawarah dilakukan bersama seluruh warga sekolah.. Hasil musyawarah ini disepakati beberapa hal sebagai berikut ini :

a. Program sosialisasi PHBS sekolah akan dilaksanakan secara berkesinambungan bekerjasama dengan pihak STIKes Respati Tasikmalaya

b. Adanya program kebersihan lingkungan secara berkala

c. Lomba kebersihan kelas

d. Pembentukan dan pelatihan kader cilik sekolah (program jangka panjang)

e. Adanya larangan merokok di sekolah

f. Pelatihan guru sekolah tentang PHBS sekolah (program jangka panjang)

3. Penyuluhan

Materi penyuluhan yang disampaikan adalah :

Kelas 1 dan 2 : Pentingnya cara menjaga kebersihan diri

Kelas 3 : waspadai dampak jajanan tidak sehat

Kelas $4 \quad$ : Menjaga lingkungan yang bersih

Kelas 5 : Mengnali dan mengelola sampah

Kelas $6 \quad$ : kader jumantik cilik

\section{G. DAFTAR PUSTAKA}

Departemen Kesehatan Republik Indonesia. 2004. Usaha Kesehatan Sekolah dalam Gambar. Jakarta: Depkes RI.

Kemendikbud.

Kemendikbud. 2012. Pedoman Pelaksanaan UKS di Sekolah. Jakarta:

Peraturan bersama antara Menteri Pendidikan dan Kebudayaan Republik Indonesia, Menteri Kesehatan Republik Indonesia, Menteri Agama Republik Indonesia, dan Menteri Dalam Negeri Republik Indonesia nomor 6/X/PB/2014, nomor 73 tahun 2014, nomor 41 tahun 2014, nomor 81 tahun 2014 tentang Pembinaan dan Pengembangan Usaha Kesehatan Sekolah/Madrasah. Jakarta.

Proverawati dan E. Rahmawati. 2011. PHBS Perilaku Hidup Bersih dan Sehat. Yogyakarta: Nuha Medika.

Hijjang, P. 2009. Perintisan Model Sekolah Sehat di Sekolah Dasar Sebagai Upaya Peningkatan Kesehatan Warga Sekolah di Kabupaten Pangkep Provinsi Sulawesi Selatan.

Supriyani, T. 2017. Laporan Kegiatan Pengabdian Masyarakat: Pembinaan Sekolah Sehat di Kawasan Kerja Puskesmas Singaparna Tahun 2017. Tasikmalaya: STIKes Respati. 


\section{H. DOKUMENTASI}
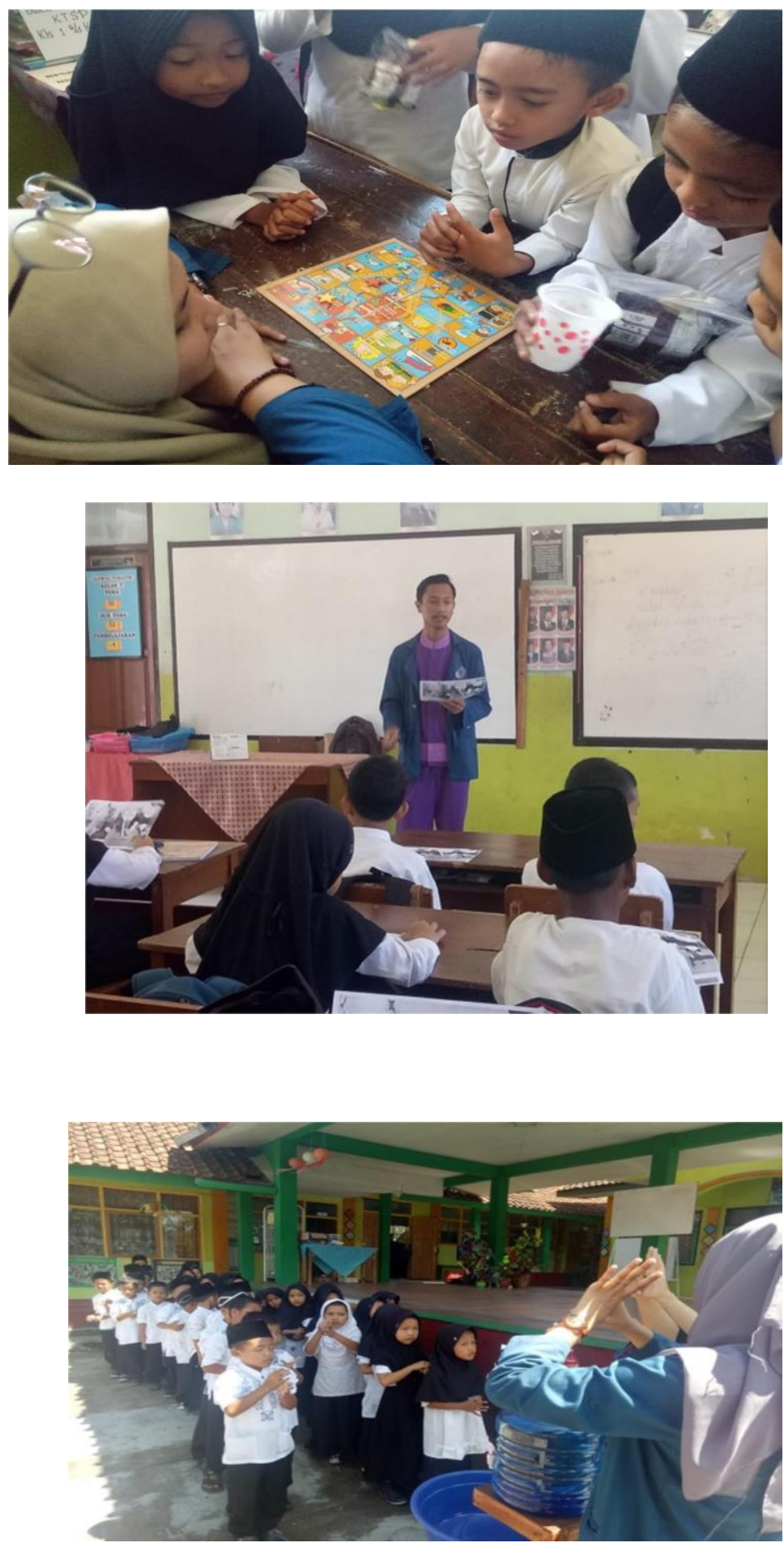